\title{
INCORPORATING RISK PREFERENCES OF FARMERS AND TECHNOLOGY IN ANALYSING THE TOTAL FACTOR PRODUCTIVITY OF RICE FARMING IN MALANG, INDONESIA
}

\author{
Agustina Shinta $^{1, *}$, Budi Setiawan ${ }^{2}$, Ratya Anindita ${ }^{2}$ and Syafrial ${ }^{2}$ \\ ${ }^{1}$ Student - The Doctoral Program, Faculty of Agriculture, Universitas Brawijaya,Indonesia \\ ${ }^{2}$ Departement of Agribusiness, Faculty of Agriculture, Universitas Brawijaya, Indonesia \\ *E-mail: shint471ub@yahoo.com
}

\begin{abstract}
The purposes of this research are a) to analyse the preference of farmers against natural and technological risks and classify them based on the use of inputs and profit, $b$ ) to analyze the influence of the farmer preferences and technology on productivity and c) to measure the total factor productivity of rice farming. The data collection method using in-depth interviews of the 305 selected farmers in the seven regions in Malang Regency (Indonesia). The research uses two planting seasons: the rainy season and the first dry season. The method of measuring risk preference is the Expected Utility of Income, stochastic frontier translog productivity function modification time dimension with MLE approach and the componentbased approach. The results show that a) $77.7 \%$ of the farmers have a preference to avoid risk, where a group of farmers with a preference for the use of inputs (seeds, labour and fertilizer) less than other types of preference, as well as gains revenues and profits; $b$ ) there is effect on the productivity of farmer preference though very small of 0.01 and $c$ ) the value of TFP involving preference is equal to 0.44 .
\end{abstract}

\section{KEY WORDS}

Component-based approach, productivity, inputs allocation.

The impact of the use of technology is one of support for agricultural policy, which is an interesting question for policy makers whether can increase the production and productivity growth. According to Balk (2001) and Coelli, et al., (1998) that the sources of productivity growth can be achieved with changes in technology, increase in technical efficiency and scale technical effort. Technology as a blue print which is indicated by the production function can be viewed as the information that must be mastered and practiced by farmers.

Fare, et al., (1994) describes the changes in technology (technical) will shift the production frontier between different periods. Thus, the concept and the reality of the changes or technological progress should not be overlooked, especially in the agricultural success increase productivity. (Semaoen, 1992). An important technological progress associated with the problem of efficiency in resource utilization are more productive, and also affect the chance of employing factor inputs and impact on income distribution. With the innovation of new technology in addition to the production increase, the use of a combination of inputs to produce products also changed so that it will cause a change in income distribution.

However, limited knowledge of farmers on the application of technology, anticipation of shifting seasons, and the natural phenomenon such as droughts and hurricanes, attacks rodents and also pests and diseases in the research area, as well as other phenomena that cannot be controlled by farmers, causing farmers are always faced with the problem of uncertainty in obtaining acceptance of revenue (Soekartawi, 1993). The uncertainty will affect the behaviour of farmers in addressing how to make decisions in allocating inputs in order to reduce or avoid the risk of production, so it will affect the production to be achieved and maximizing profits. According to Ellis, 1988 and Wik, et al., 1998 that avoidance behaviour against the risk of production will cause the resulting production will be lower than the farmers who behave as risk lover, so the impact on the low income due to low or unwillingness of farmers to adopt the technology. 
Malang Regency (Indonesia) is a regency that can produce high paddy productivity. Agro-ecosystem conditions, rainfall, soil type and topography in the area is sufficient support for paddy farming. Although high, the production still has not been able to meet the rice needs of the regency. The rate of productivity on land factor achieved during 13 years of this condition is not stable, sometimes rise and fall sharply. Problems that occur almost every year, namely the existence of natural phenomena such as hurricanes, attacks of leafhoppers, rodents, birds, rice white stemborer (Scirpophaga innotata), rice blast fungus, rice rotten neck (Pyricularia grisea), drought and flooding. Due to this natural phenomena, make the farmers suffered crop losses for about $10-50 \%$. In addition to natural phenomena, the application of technology is also a problem. Different technology adoption resulted in the decision making in the allocation of inputs is also different. Thus, the alleged preference of farmers against natural risks and the technology will have an impact on production and the growth of total factor productivity.

Some research results are summarized in the book of Ellis (1988) about the preference of farmers against the risk are (1) peasant risk averter lead to inefficient use of resources, peasant risk averter led to the design of cropping pattern is only intended to increase the food security of subsistence and not the maximization of output, (2) peasant risk averter obstructs the process of diffusion and adoption of innovation, which is defined as the risk characteristics of the information gaps, and peasant risk averter will decline with increasing incomes. Farmers who behaves risk averter will produce lower than farmers who behaves risk neutral and if there is an increased risk, thus farmers of risk averter will reduce the output (Ellis, 1988 and Wik, et al., 1988). Measurements preference of farmers against the risk of farming conducted by the earlier researchers with several approaches include using a) the approaches of variance value, standard deviation and coefficient of variation (Siddik, 2015);

b) Expected Utility of Income approach (Ellis, 1988) using the Bernoulli principle, technical Neumann - Morgenstern, Arrow Pratt Theory and quadratic utility function (Lwayo, 2012 and Ratnasari, 2013) and c) perception approach of production risk undertaken by Putri (2014). The research found that farmers risk behaviours vary by type of commodity. Behavioural risk averse contained on farmers who grow food crops, vegetables and organic ( Fariyanti (2008), Saptana (2012), Ratnasari (2013)), while farmers who plant crops have behavioural risk taker (Fauziyah (2010), and Siddik (2015)). Whereas, this research will use the Expected Utility of Income approach to analyse the preferences of farmers against the risks and classification based on the use of farming inputs and profits.

Preferences farmers against risk is a very important aspect in the formulation of government policy and decision-making by farmers according to Just and Pope (1978), Pope and Kramer (1979), Griffiths and Anderson (1982) and Wan, et al., (1992). According Battese, et al., (1994) that incorporate the risk of production on stochastic frontier production function is the essence of things related to the prediction of technical efficiency, because the measurement of technical efficiency measures the degree of usefulness of the technology adopted in the production process. Approach by Just and Pope (1979) shows the influence the allocation of inputs that can decrease or increase the risk of production using the average production function and the production function variance. Meanwhile, research on the rate of total factor productivity conducted by several researchers either using non-parametric and parametric, as follows Constantin, et al., (2009), Fare, et al., (1984), Casu (2002), Ozden and Santos (2006), Kumbhakar and Sun (2010); whereas Karagiannis (2001) using parametric methods in the various sectors. However, research have not found TFP by inserting variable of farmer preference for risk. Thus study is more complete because the variable preference of farmers to be included in the risk analysis and measurement of productivity frontier total factor productivity.

\section{MATERIALS AND METHODS}

Data collection is conducted in the rainy season of 2013 and the first dry season of 2014, using in-depth interviews to paddy farmers of 305 people, thus the total observation as many as 610 farmers. The location selected purposively with consideration that regions with 
high productivity gains, but the rate of productivity on land during 13 years fluctuate sharply. The methods of data analysis are the expected utility of income, stochastic frontier translog productivity function and the component-based approach.

Methods of data analysis:

a) Measurement of Farmers' Risk Preferences and classification those results based on the use of inputs and profit

The concept of preference farmers against farm risk to explain how farmers face barriers as the risk of personal power in decision-making on the basis of trust on the occurrence of an uncertain event and a personal evaluation of the potential consequences. Barriers of risk farming measured by risk approach as the possibility of the phenomena / natural phenomena such as droughts, storms, pests and diseases, heavy rainfall, and changes in policy / government programs such as changes of government purchasing price, retail price, supports of production tools, extension, and technology. The formulas used are:

$$
\begin{aligned}
& \mathrm{EMV}=p_{1} \cdot \mathrm{I}_{\mathrm{a} 1}+p_{2} \cdot \mathrm{I}_{\mathrm{a} 2} \\
& \mathrm{E}(\mathrm{U})=p_{1} \mathrm{U}\left(\mathrm{I}_{1}\right)+p_{2} \cdot \mathrm{U}\left(\mathrm{I}_{2}\right) \\
& \text { Utility of Income }{ }_{1}\left(\mathrm{U}\left(\mathrm{I}_{1}\right)\right)=\mathrm{E}\left(\mathrm{Py}_{1}\right)^{*} \mathrm{E}\left(\mathrm{Y}_{1}\right) \\
& \text { Utility of Income }{ }_{2}\left(\mathrm{U}\left(\mathrm{I}_{2}\right)\right)=\mathrm{E}\left(\mathrm{Py}_{2}\right)^{*} \mathrm{E}\left(\mathrm{Y}_{2}\right)
\end{aligned}
$$

EMV (Expected Money Value) is the expectation of the actual average income on the perception of two seasons. $E(U)$ (Expected Utility) is the sum of the utility derived from the income expectations of the risks that may occur in two seasons. EMV - $E(U)$ is an opportunity value of money earned, where it shows a preference of farmers against risks. With indicators that: said that risk averter when $\mathrm{I}_{\mathrm{a}}<\mathrm{EMV}$, this indicates that a farmer is indifferent between $I_{a}$ and EMV, meaning that farmers are prepared to lose some income by EMV - $I_{a}$ in order to achieve certainty; said that risk taker when $I_{b}>E M V$, this indicates that a farmer takes the opportunity to generate the highest income and said that risk neutral when $I_{c}$ $=E M V$, this indicates that a farmer facing the expected income from farm $U(I)$ equal with the expected utility $\mathrm{E}(\mathrm{U})$ on two conditions. Description: $p_{1}=$ probability of income on perception of a good season, $p_{2}=$ probability of income on perception of a bad season, $l_{1}=$ expected income during the rainy season, $\mathrm{I}_{2}=$ expected income during the dry season, $\mathrm{I}_{\mathrm{a} 1}=$ actual income during the rainy season, $I_{\mathrm{a} 2}=$ actual income in the dry season, $E(P y 1)=$ expected output prices are based on the risks that accompany on the rainy season, $E(Y 1)=$ expected harvests are based on the risks that accompany on the rainy season, $E(P y 2)=$ expected output prices are based on the risks that accompany on the dry season, $E(Y 2)=$ expected harvests are based on the risks that accompany on the dry season.

Selection of a good season is the perception of farmers looking at a season (rainy and dry seasons) could provide more incomes than other seasons, and vice versa. Likewise, the perception of changes in government policies and programs become a reference in the probability of selecting the best possible results. Results of the analysis of risk measurement above, will result farmers preference consisting of farmers of risk averter, farmers of risk taker or farmers of risk neutral.

While, the measurement of profit using a formula of total revenue minus by total cost. Total revenue is the result of multiplying the production $(\mathrm{kg})$ by the production price (IDR) each planting season. Total cost is the sum of all costs incurred by farmers in the planting season, such as the purchases of seeds, urea fertilizer, ZA fertilizer, NPK Phonska fertilizer, organic fertilizer, SP36 fertilizer, the cost of woman labour, the cost of man labour, solid chemical drugs, liquid chemical drugs, tractor rent cost and rent / land tax, all costs are counted in IDR. Once obtained the preferences group, then grouped based on use of inputs and profit earned.

\section{b) Analysis of The Influence of Farmers's Preference to Productivity}

The parameters of stochastic frontier translog productivity function with time dimension is estimated using Maximum Likelihood estimators. Completion of the model using Frontier 4.1 software program. The equation is: 


$$
\begin{gathered}
\mathrm{Y}_{\mathrm{it}}=\exp \left(\beta_{0}+\beta_{t}+\frac{1}{2}\left(\beta_{t t}\right)^{2}+\sum_{h=1}^{N} \beta_{h i t} \ln x_{h i t}+\frac{1}{2}\left(\beta_{h_{i t} h_{i t}}\right)^{2}+\right. \\
\left.\sum_{h=1}^{N} \beta_{h i t} \ln x_{h i t} t+\sum_{h=1}^{N} \sum_{m=1}^{N} \beta_{h_{i t} m_{i t}} \ln x_{h i t} \ln x_{m i t}+\sum_{h=1}^{N} \sum_{m=1}^{N} \beta_{h_{i t} m_{i t}} \ln x_{h i t} \ln x_{m i t} t+\text { Dtekn }+P R\right)+ \\
v_{i}-u_{i}
\end{gathered}
$$

where: $\beta_{\text {hit }}$ : alleged parameters for input to the $\mathrm{h}$-th on the productivity frontier in individuals to the $\mathrm{i}$-th on growing season to the $\mathrm{t}$-th, $\beta_{\mathrm{hm}}$ : alleged parameters for interaction input to $\mathrm{h}$-th with an input to the $\mathrm{m}$-th toward frontier productivity, $\ln \mathrm{Y}_{\mathrm{it}}$ : productivity of dry-milled rice on individual to the $\mathrm{i}$-th in the growing season to the $\mathrm{t}$-th $(\mathrm{kg}), x_{\text {hit }}$ : input to the $\mathrm{h}$-th on individual to the $\mathrm{i}$-th in the growing season to the $\mathrm{t}$-th, $\ln x_{\text {hit }} \ln x_{\text {mit }}$ : natural lag which shows the interaction between inputs used on each individual to the $i$-th and the growing season to the $\mathrm{t}$-th, $\mathrm{e}_{\mathrm{it}}=\mathrm{v}_{\mathrm{it}}-\mathrm{u}_{\mathrm{it}}, \mathrm{u}_{\mathrm{it}}=$ random variable of non-negatively associated with technical inefficiency, $\mathrm{N}\left(0, \sigma_{u}^{2}\right), \mathrm{v}_{\text {it }}=$ statistical errors iid $\mathrm{N}\left(0, \sigma_{v}^{2}\right)$, Dtekn = dummy technology where the number 0 indicates not to apply the technology and number 1 show applying technology. Input variables are seed, urea, ZA, NPK Phonska, SP-36, organic fertilizers, male labour, female labour, a solid chemical drugs and a liquid chemical drugs. PR is the preference of farmers to risk, where risk taker notated as 3 , risk neutral notated as 2 and risk averter notated as 1 .

The hypothesis is $H_{0}: \alpha_{\mathrm{hm}}=\alpha_{\mathrm{h}}=\beta_{\mathrm{hm}}=\beta_{\mathrm{m}}=0$; (no influence of variables independent of the productivity), besides other hypotheses are changes in technical is neutral using the input if and only if $\beta_{h t}=0$ and no changes if and only if $\beta_{t}=\beta_{t t}=\beta_{h t}=\beta_{h m t}=0 . t$ raises on the regression in order to capture the impact of technical changes. Econometric problem here is to separate the role of t namely as a proxy for technical changes to the kernel deterministic to stochastic frontier production and as an indicator of changes in technical efficiency on the second error component.

c) Measurement of Total Factor Productivity

The method is used the Component-based approach initiated by Balk, is the multiplication of technical change $(\widehat{T} \Delta)$, changes in technical efficiency $(T \hat{E} \Delta)$ and changes in technical scale $((\mathrm{S} \widehat{T} \Delta))$, where:

$$
\begin{aligned}
& \hat{T} \Delta=\hat{\beta}_{t}+\hat{\beta}_{t t} t+\sum_{h=1}^{n} \beta_{h t} \ln x_{h i t} \\
& \mathrm{~T} \hat{E} \Delta=\hat{u}_{i} \cdot \hat{\rho} \cdot \exp (-\hat{\rho}(\mathrm{t}-\mathrm{T})) \\
& \left.(\mathrm{S} \hat{T} \Delta)=\hat{\xi}_{b}+\left(\hat{\xi}_{u}\right)+\left(\hat{\xi}_{z a}\right)+\widehat{\xi}_{p s}\right)+\left(\hat{\xi}_{s p}\right)+\left(\hat{\xi}_{o}\right)+\left(\hat{\xi}_{t l}\right)+\left(\hat{\xi}_{t p}\right)+\left(\hat{\xi}_{o b k}\right)+\left(\hat{\xi}_{o b l}\right)
\end{aligned}
$$

For more details see Appendix 1.

\section{RESULTS AND DISCUSSION}

Results of Farmers Risk Preferences and Classification those Results Based on the Use of Inputs and Profit.

The results show that the highest number of preference of paddy farmers against natural and technological risks are farmers who prefer to avoid the risk or risk averter by $77.70 \%$, farmers who prefer to risk or risk taker by $20.30 \%$ and farmers who neutral to risk by $1.97 \%$.

Farmers' profile of risk averter: the average land area is 0.43 hectares, consisting of $91.14 \%$ of land under the control of one hectare and $21 \%$ of farmers own the land over 1 hectare. From $21 \%$ of farmers, $19 \%$ farmers had more than 2 hectares of land areas. Land ownership status is a self-owned (83.33\%) and rent-owned systems of $16.67 \%$. The average age of farmers is 53 years old, the average education level is junior high school, but the most distribution is level education of elementary high school of $46.41 \%$, and there is also undergraduate level of $1.27 \%$. The average length of farming is 22 years. The average land status of farmers is partly land rents and self-owned of $88.19 \%$ and $11.81 \%$ are self-owned. The number of farmers who implement the technology of $54.43 \%$, and the remaining $45.57 \%$ is not applying the technology.

Farmers' profile of risk taker: the average age of 55 years old with an average farming experience is over 25 years. Average land size of 0.643 hectares, with details of land is 1 2.5 hectares of $25.81 \%$ and under 1 hectare of $74.19 \%$. The education level is $43.55 \%$ for 
elementary high school, junior high school of $24.19 \%$, senior high school of $27.42 \%$ and undergraduate level of $4.84 \%$. There is a tendency of farmers risk taker who prefer the challenge of farming, it is shown on the characteristics of farmers' land size. Approximately $82.26 \%$ of farmers as risk taker who have land size is a combination of self-owned and rented land to other farmers. Meanwhile, farmers who farming on their own land are only $8.06 \%$ and farmers who rent land are $9.67 \%$.

Farmers' profile of risk neutral: the average age is 50 years old with an average farming experience is 18 years. Education level is $66.67 \%$, junior and elementary high school levels are $16.67 \%$. The average land ownership is 0.63 hectares, consisting of $66.67 \%$ of the farmers who control the land under one hectare and $33.33 \%$ of the farmers who own the land over 1 hectare. The average land size is 0.61 hectares, of which 46 farmers or $74.19 \%$ have an area less than 1 hectare and $25.8 \%$ has a land area of more than 1 hectare.

Use of Input based on Farmers' Preference.

a. The Use of Seed

Seeds used by farmers in the research area are varied, most farmers use paddy varieties such as IR-64, Inpari 30, Inpari 7, Sidenok 2013, Cibogo 2014, Ciherang, Situ Bagendit, Mekongga, Cibogo, Way apu buru, and Towuti (Indonesian non-hybrid rice vareties). While, hybrid paddy varieties include Hybrid 68, Sembada 168 and Hybrid 2011 (Indonesian hybrid rice vareties). Farmers of $75 \%$ planted using seed varieties of Ciherang, because it resistance to bacterial blight, and suitable to be planted in the lowland. Ciherang is a cross between the varieties of $I R$ with plant age of 116-125 days with fluffy rice texture and the average production of 6 tons / hectare and the potential yield is 8 tons / hectare.

Risk neutral farmers are minimum using rice seeds during the rainy season compared to risk averter farmers and risk taker farmers of $11.73 \mathrm{~kg}$. But in the dry season, the seeds used by risk averter farmers is minimum of $12 \mathrm{~kg}$. (See: Table 1). The government's recommendation to use the seed between 15 to $25 \mathrm{~kg}$, depending on the technology used. The use of rice seeds which approached the government' recommendation risk taker farmers (Figure 1).

Table 1 - The Use of Seed (Kg) Based on Farmers' Preference

\begin{tabular}{lcccc}
\hline \multicolumn{1}{c}{ Season } & Risk Averter & Risk Neutral & Risk Taker & Recommendation \\
\hline \hline Rainy & 12.00 & 11.73 & 13.79 & 15 \\
Dry & 12.00 & 12.54 & 13.61 & 15 \\
\hline
\end{tabular}

b. The Use of Fertilizer

Fertilizer used is Urea, ZA, Phonska, SP-36 and Organic fertilizers. Each fertilizer has the function, benefit and the recommended use its own. Urea fertilizer needed paddy plants to meet the needs nutrients of nitrogen $(\mathrm{N})$, where the nitrogen has the function of making the leaves into a fresh green that contains many grains of green leaves that required in the photosynthesis process, therefore accelerates vegetative growth of the plants (height, number of tillers, shoots and others). Nitrogen impact on increasing the production and protein content of the crop. Recommendation of fertilizer uses per hectare for paddy farming is $200-300 \mathrm{~kg}$. Risk taker using urea fertilizer almost accordance with the recommendation compared with other types of farmers' preferences both the rainy season and the dry season.

ZA fertilizer is a fertilizer containing nutrients of nitrogen $(N)$ and sulphur (S). The functions of both are almost the same that help the formation of the green grains and adding protein and vitamins in paddy plants. In addition, a role in the synthesis of oil in the manufacturing process of sugar in grains. The recommendation use of ZA fertilizer use does not need excessive, because the nutrients of nitrogen are contained in the fertilizer of urea and NPK Phonska fertilizers. Risk neutral using ZA fertilizer almost in accordance with the recommendation by the government than any other farmers' preference in the rainy season, but not for the dry season.

NPK Phonska fertilizer used by farmers, the fertilizer has a nitrogen content, phosphorus and potassium, then those fertilizers have many benefits, ranging from the growth of leaves, roots, buds, flowers and fruit. The recommendation of government of NPK 
Phonska fertilizer use of 200-350 kg per hectare with the assistance of urea fertilizer use of 150-200 kg. Although the use of NPK Phonska fertilizer exceed the government's recommendation, but still within normal limits, which is carried out by neutral risk farmers both on rainy and dry seasons.

SP-36 fertilizer is used to meet the nutrient needs of Phosphate $(P)$ which useful to stimulate the growth and system of root, thus in the retrieval process of nutrients will get more output. When plant growth is healthy and vigorous, the plant will have a resistance to pests and diseases. In addition to the roots, phosphate needed in the generative process of plant which accelerates the formation of flowers and ripening fruit / seed, so that accelerates the harvest time. Recommendation of SP-36 fertilizer use is 100-150 kg per hectare. SP-36 fertilizer use for all kinds of preferences is still below the government's recommendation. Fertilizer use of approaching the recommendation is risk averter farmers.

Organic fertilizer contains macro nutrients $(\mathrm{N}, \mathrm{P}, \mathrm{K})$ and micro nutrients $(\mathrm{Ca}, \mathrm{Mg}, \mathrm{Fe}, \mathrm{Mn}$, Bo, S, Zn, and Co) that can improve the fertility soil structure, increase the soil to holding water and nutrients (moisture), improve the soil chemical properties that will happen the binding system and release the ions in the soil, so that it can support plant growth of Cation Exchange Capacity (CEC), improving the condition of soil biology, which is stimulating soil microorganisms beneficial such as rhizobium, mycorrhizae and bacterial decomposition of phosphate or potassium, the concentration of $\mathrm{O}_{2}$ and $\mathrm{CO}_{2}$ in relation to the biological activity of the soil, improve the condition soil physical, that is capable of binding water by organic fertilizer can make a better porosity of the soil, thus it can support respiration and growth of plant roots. Recommendation use of organic fertilizer is quite a lot that is $500 \mathrm{~kg}$ per hectare. The use of organic fertilizer for all kinds of preference is still below the government's recommendation. Fertilizer use of approaching the recommendation is risk taker farmers. (See: Table 2 and Fig. 2, 3).

Table 2 - The Use of Fertilizer $(\mathrm{kg})$ and Outcome (\%) Based on Farmers' Preference

\begin{tabular}{ccccccccc}
\hline Season & Fertilizer & $\begin{array}{c}\text { Risk } \\
\text { Averter }\end{array}$ & Outcome & $\begin{array}{c}\text { Risk } \\
\text { Neutral }\end{array}$ & Outcome & $\begin{array}{c}\text { Risk } \\
\text { Taker }\end{array}$ & Outcome & Recommendation \\
\hline \hline Rainy & Urea & 297.6 & 99.2 & 362.2 & 120.7 & 302.0 & $\mathbf{1 0 0 . 7}$ & 300 \\
Season & ZA & 107.1 & 53.6 & 258.3 & $\mathbf{1 2 9 . 2}$ & 162.7 & 81.4 & 200 \\
& Phonska & 161.2 & 80.6 & 242.0 & $\mathbf{1 2 1 . 0}$ & 243.9 & 121.9 & 200 \\
& SP-36 & 121.7 & $\mathbf{8 1 . 1}$ & 10.1 & 6.7 & 24.5 & 16.3 & 150 \\
& Organic & 247.3 & 49.5 & 192.4 & 38.5 & 322.5 & $\mathbf{6 4 . 5}$ & 500 \\
\hline Dry & Urea & 298.2 & $\mathbf{9 9 . 4}$ & 365.6 & 121.9 & 298.1 & $\mathbf{9 9 . 4}$ & 300 \\
Season & ZA & 108.3 & 54.2 & 258.3 & 129.2 & 198.4 & $\mathbf{9 9 . 2}$ & 200 \\
& Phonska & 162.2 & 81.1 & 242.0 & $\mathbf{1 2 1 . 0}$ & 254.0 & 127.0 & 200 \\
& SP-36 & 122.3 & 81.5 & 170.6 & 113.8 & 161.7 & $\mathbf{1 0 7 . 8}$ & 150 \\
& Organic & 246.2 & 49.2 & 192.0 & 38.4 & 342.0 & $\mathbf{6 8 . 4}$ & 500 \\
\hline
\end{tabular}

c. The Use of Labour in Paddy Farming

The use of labour is grouped into two types of labour based on gender, namely the use of labour of man and woman. Labour needed in large quantities because of the many paddy farming activities. Activities in paddy farming each season, such as: land preparation, preparation 1 (tamping, mopok, kaliundang, larikan (Java term)), preparation 2 (dadaki, daut, larikan (Java term)), spraying the herbicide, fertilizing basic / organic, planting, fertilizing additional I (Urea and Phonska), first weeding, fertilizing additional II, second weeding, fertilizing additional III, irrigation, spraying plant growth regulator / liquid organic fertilizer, spraying for pests / diseases, the beginning of the harvest (wiwit, metik (Java term)), and drying. Woman labour is minimum used by risk neutral farmers in the dry season, while in the rainy season, the minimum woman labours are risk averter farmers (See: Table 3 and Fig 4).

Table 3 - The Use of Labour (Man-day)

\begin{tabular}{ccccc}
\hline Season & Labours & Risk Averter & Risk Neutral & Risk Taker \\
\hline \hline Rainy & Man & 70 & 79 & 83 \\
& Woman & 64 & 73 & 75 \\
Dry & Man & 70 & 77 & 81 \\
& Woman & 64 & 61 & 68 \\
\hline
\end{tabular}


d. The Use of Chemical Drug Solids and Liquids

The use of solid chemical drug is used for spraying pests such as the brands of Furadan and Recunin. While, the liquid chemical drugs used such as the brands of virtako, matador, decis, score, gramoxon, ripcord, corfidor, and nugrass. The calculation of solid chemical drug use is only include the use of Furadan and Recunin brands, which is the mainstay for farmers to eradicate stem borer attack. The use recommendation of solid chemical drugs adjusted by the volume of stem borer attack. It can also be given as a preventive before the attack, but it is not recommended to be done.

The use of most chemical drugs are risk neutral farmers both the rainy season and the dry season, and instead use the minimum amount of chemical drugs are risk taker farmers. Risk taker farmers using solid chemical drugs on stem borer attack, it is not used for preventive (Table 4 and Figure 5).

Dominant use of liquid chemical drugs in the research area is the brand of virtako, matador, decis, score, and other brands. In the rainy season, the use of liquid chemical drugs most used by risk averter farmers of 2.81 litters / hectare, and the minimum used by risk taker farmers of 1.13 litters per hectare (Table 4 and Figure 6). Whereas in the dry season, risk neutral farmers use a liquid chemical drugs most of 4.24 litters per hectare (Figure 6). The expectations of one of these farmers is the use of the matador and virtako brands can eradicate the brown planthopper pests which attack paddy plants.

Table 4 - The Use of Chemical Drug

\begin{tabular}{ccccc}
\hline Chemical Drug & Season & Risk Averter & Risk Neutral & Risk Taker \\
\hline \hline Solid & Rainy & 9.77 & 11.65 & 6.17 \\
(kilogram) & Dry & 9.74 & 11.58 & 6.47 \\
Liquid & Rainy & 2.81 & 1.68 & 1.13 \\
(litter) & Dry & 2.82 & 4.24 & 2.62 \\
\hline
\end{tabular}

Total Cost, Revenue and Profit by Farmers' Preference

a. The Profit of Farmers Based on Farmers' Preference in the rainy season

Total cost is the sum of the costs incurred by farmers during farming activities. Thus, the cost for harvesting in addition to labour, transportation and marketing are not taken into account. In the rainy season, risk taker farmers spend the greatest cost of IDR 8,978,027 compared to risk neutral and risk averter farmers. This is due to the purchase of inputs (urea, ZA and SP-36 fertilizers) incurred by risk taker farmers more than other farmers.

Table 5 - Profit Based on Farmers' Preference on Rainy Season (IDR)

\begin{tabular}{cccc}
\hline Variables & Risk Averter & Risk Neutral & Risk Taker \\
\hline \hline Total Cost & $6,616,782$ & $8,574,596$ & $8,978,027$ \\
Revenue & $26,344,580$ & $35,711,111$ & $30,801,229$ \\
Profit & $19,727,798$ & $27,136,515$ & $21,823,202$ \\
\hline
\end{tabular}

The average production produced by risk averter farmers is 6.29 tons / hectare and output prices of IDR 4,258 then the average revenue obtained is IDR $26,344,580$. While the risk neutral farmers can produce an average production of 8.56 tons / hectare with average price of harvest of IDR 4,166 thus, the average revenue is IDR 35,711,111. Risk taker farmers can produce an average production of 8.72 tons / hectare with an average price of harvest of IDR 4,139 so that the average revenues is IDR 30,801,229. In accordance with the theory, that farmers are behaving prefer on risk will get higher production than the others, it is because risk taker farmers take the decisions of efficient input use.

However, because of the price obtained at the time of harvest is lower than the risk neutral farmers, the farmers revenue of risk taker are lower than risk neutral farmers (Table 5 and Figure 7). 
b. The Profit of Farmers Based on Farmers' Preference in the Dry Season

Risk taker farmers spend most cost compared to other farmers in the dry season (Table 6), which is in line with the perception of risk taker farmers have a great hopes in the dry season, so that farmers dare to allocate their resources as efficiently as possible.

Table 6 - The Profit Based on Farmers' Preference in the Dry Season

\begin{tabular}{cccc}
\hline Variable & Risk Averter & Risk Neutral & Risk Taker \\
\hline \hline Total Cost & $6,779,544$ & $8,249,077$ & $9,230,907$ \\
Revenue & $26,949,306$ & $34,222,222$ & $36,662,980$ \\
Profit & $20,169,763$ & $25,973,145$ & $27,432,073$ \\
\hline
\end{tabular}

Production in the dry season is not much different from the rainy season, the production received by farmers of risk averter, risk neutral and risk taker are 6.83 tons / hectares, 8.56 tons / hectare and 8.73 tons / hectare respectively. However, for the harvest prices are different between dry season and rainy season. Risk averter farmers earn an average price of IDR 4,255, harvest prices of risk neutral farmers amounted of IDR 4,000 and the harvest price of risk taker farmers amounted of IDR 4,203. So that the largest revenue received by risk taker farmers of IDR 36,662,980 (Table 6 and Figure 8). Revenue with increase significantly is risk taker farmers from IDR $21,823,202$ to $27,432,073$ while the decrease in revenues occurred in risk neutral farmers from IDR 27,136,515 to IDR $25,973,145$. There is a slight increase on averter risk farmers from the rainy season to the dry season.

Result of Influence Farmers's Preferences Risk on Productivity.

The first step is build a stochastic frontier translog productivity function with time modification. The above equation solved by a single equation estimation procedure of MLE (Maximum Likelihood Estimation) approach using Frontier version 4.1.c. Variance parameter of the likelihood function estimated on $\sigma^{2}=\sigma_{v}^{2}+\sigma_{u}^{2}$ dan $\Upsilon=\sigma_{u}^{2} / \sigma^{2}$ and $\Upsilon=\sigma_{u}^{2} / \sigma^{2}$, as for the result is $\sigma_{v}^{2}=0.31$ and $\sigma_{u}^{2}=0.259$ so that $\sigma^{2}$ at 0.455 . According to Gujarati (2013) that the larger the sample used for the estimation of $\mathrm{ML}$, then $\sigma^{2}$ will converge towards the real $\sigma^{2}$, and the difference estimator will be smaller between OLS and MLE estimates. By putting the value from estimator on log likelihood function, the obtained value of the log likelihood function when the OLS at -457.5 and the maximum value of -113.3 that no other values of the parameters which will provide a higher probability in the analysis

While the value of $\Upsilon$ for 0.906 indicates that the estimated value of $\Upsilon$ approaches a value of 1 , states that the highest probability, that impact of inefficiency is significant on stochastic frontier models, and the average production function is not sufficiently represent the technology of farming. It means that the gamma of 0.906 indicates that for $90.6 \%$ of the total variation of rice production with a confidence level of $99 \%$ for farmers, due to the technical inefficiency among farmers. In other words, that of rice production can be optimized if the technical inefficiency among farmers is minimized.

Some hypotheses can be tested using the generalized statistical likelihood-ratio, where LR test of 688.5 obtained of log likelihood $\mathrm{H}_{0}$ and $\mathrm{H}_{1}$, restriction 3 is greater than the critical point on $99.5 \%$ confidence level of 12.84 , means that the alternative hypothesis is accepted.

Among others, 1) that the independent variables have an influence on the dependent variable on equation of technical efficiency, 2) that the independent variables have an influence on the dependent variable on equation technical inefficiency and 3) $\Upsilon$ is a stochastic variable.

From the frontier analysis, partially from 92 variables there are 36 independent variables that significantly affect the dependent variable. The factors that affect positively and significantly to productivity are urea and NPK Phonska fertilizers, otherwise factors that affect negatively and significant are the use of ZA, SP-36 and organic fertilizers. There is effect on the productivity of farmers's preference though very small of 0.01 . 
Table 7 - Frontier Translog Productivity Function of Time Modification (with consideration of the preferences of farmers against the risk)

\begin{tabular}{|c|c|c|c|c|c|c|c|c|}
\hline No & Variable & $\begin{array}{l}\text { Parameter } \\
\text { Estimation }\end{array}$ & No & Variable & $\begin{array}{l}\text { Parameter } \\
\text { Estimation }\end{array}$ & No & Variable & $\begin{array}{l}\text { Parameter } \\
\text { Estimation }\end{array}$ \\
\hline 1 & $\ln A$ & -0.3584 & 34 & $\ln \mathrm{A} \ln \mathrm{OL}$ & "-0.02899 & 67 & In PS In OK & 0.0152 \\
\hline 2 & $\ln B$ & 0.32 & 35 & AT & 0.16925 & 68 & In PS In OL & 0.0063 \\
\hline 3 & $\ln U$ & $0.769^{*}$ & 36 & In B In U & -0.03659 & 69 & PST & $-0.232^{*}$ \\
\hline 4 & $\ln Z A$ & $-0.98678^{*}$ & 37 & $\ln B \ln Z A$ & $-0.03135^{\star}$ & 70 & In SP In O & $-0.0064^{*}$ \\
\hline 5 & In PS & $0.4^{*}$ & 38 & $\ln B \ln P S$ & $0.02667^{\star}$ & 71 & In SP In TL & 0.0061 \\
\hline 6 & In SP & $-0.2557^{*}$ & 39 & $\ln B \ln S P$ & -0.00133 & 72 & In SP In TP & $0.0238^{*}$ \\
\hline 7 & $\ln O$ & $-0.144^{\star}$ & 40 & $\ln B \ln O$ & $-0.0206^{\star}$ & 73 & In SP In OK & $0.0125^{*}$ \\
\hline 8 & $\ln \mathrm{TL}$ & -0.121 & 41 & In B In TL & -0.05568 & 74 & In SP In OL & $0.0114^{*}$ \\
\hline 9 & In TP & 0.66 & 42 & In B In TP & $0.0753^{*}$ & 75 & SPT & 0.09 \\
\hline 10 & In OK & -0.246 & 43 & $\ln B \ln O K$ & -0.00713 & 76 & $\ln \mathrm{O} \ln \mathrm{TL}$ & -0.0129 \\
\hline 11 & In OL & -0.0588 & 44 & In B In OL & -0.00237 & 77 & In O In TP & -0.0123 \\
\hline 12 & $\mathrm{~T}$ & $6.7^{* \star \star \star *}$ & 45 & BT & 0.2049 & 78 & In O In OK & 0.0004 \\
\hline 13 & $\ln A \ln A$ & $-0.155^{\star}$ & 46 & $\ln U \ln Z A$ & -0.0038 & 79 & In O In OL & $-0.0125^{\star \star *}$ \\
\hline 14 & $\ln B \ln B$ & -0.096 & 47 & In U In PS & 0.00128 & 80 & OT & $0.152^{\star \star \star \star}$ \\
\hline 15 & $\ln U \ln U$ & $0.08366^{*}$ & 48 & In U In SP & 0.006162 & 81 & In TL In TP & -0.0018 \\
\hline 16 & $\ln Z A \ln Z A$ & $0.064^{* \star * *}$ & 49 & $\ln U \ln O$ & $0.0088^{* \star *}$ & 82 & In TL In OK & $-0.0494^{\star}$ \\
\hline 17 & In PS In PS & 0.01588 & 50 & $\ln U \ln T L$ & -0.01888 & 83 & In TL In OL & 0.0012 \\
\hline 18 & In SP In SP & 0.0366 & 51 & In U In TP & -0.0182 & 84 & TLT & 0.211 \\
\hline 19 & $\ln \mathrm{O} \ln \mathrm{O}$ & $0.02489^{* * *}$ & 52 & In U In OK & $0.0138^{\star}$ & 85 & In TP In OK & $0.0358^{*}$ \\
\hline 20 & In TL In TL & $0.1543^{\star}$ & 53 & In U In OL & $-0.0146^{\star * *}$ & 86 & In TP In OL & $0.031^{*}$ \\
\hline 21 & In TP In TP & -0.08778 & 54 & UT & $-0.6966^{*}$ & 87 & TPT & -0.386 \\
\hline 22 & In OK In OK & 0.0138 & 55 & In ZA In PS & -0.0058 & 88 & In OK In OL & 0.0014 \\
\hline 23 & In OL In OL & $0.0387^{* * * *}$ & 56 & $\ln Z A$ In sp & -0.00376 & 89 & OKT & $0.165^{*}$ \\
\hline 24 & $\mathrm{TT}$ & $-5.085^{\star \star * *}$ & 57 & $\ln Z A \ln O$ & 0.00258 & 90 & OLT & 0.0073 \\
\hline 25 & LN A LN B & -0.0767 & 58 & $\ln \mathrm{ZA} \ln \mathrm{TL}$ & 0.0175 & 91 & dtehn & 0.0148 \\
\hline 26 & $\ln A \ln U$ & -0.01126 & 59 & In ZA In TP & 0.00517 & 92 & PR & 0.01 \\
\hline 27 & $\ln A \ln Z A$ & -0.02367 & 60 & In ZA In OK & 0.00211 & \multicolumn{3}{|c|}{ Hypothesis Test } \\
\hline 28 & $\ln A \ln P S$ & $0.05574^{* *}$ & 61 & $\ln \mathrm{ZA} \ln \mathrm{OL}$ & -0.00845 & 1 & LR test & 688.85 \\
\hline 29 & $\ln A \ln S P$ & $-0.0211^{*}$ & 62 & ZAT & $0.855^{*}$ & 2 & $\begin{array}{l}\text { sigma- } \\
\text { squared }\end{array}$ & $0.259^{\star \star \star *}$ \\
\hline 30 & $\ln \mathrm{A} \ln \mathrm{O}$ & -0.0188 & 63 & In PS In SP & 5.39E-05 & 3 & $Y$ & $0.906^{* * * *}$ \\
\hline 31 & $\ln A \ln T L$ & -0.0231 & 64 & In $P S \ln O$ & 0.00365 & 4 & Restriction & \\
\hline 32 & $\ln A \ln T P$ & 0.0331 & 65 & In PS In TL & $-0.04335^{\star}$ & 5 & $\mathrm{Mu}$ & $0.69^{* * * *}$ \\
\hline 33 & In A In OK & -0.0329 & 66 & In PS In TP & -0.02188 & 6 & Eta & $-0.213^{\star * * *}$ \\
\hline
\end{tabular}

${ }^{* * *} \operatorname{sign} 99.5 \%,{ }^{* * *} \operatorname{sign} 97.5 \%,{ }^{* *} \operatorname{sign} 95 \%$ and ${ }^{*} \operatorname{sign} 90 \%$.

c. Result of Total Factor Productivity Measurement

Total Factor Productivity size according to Balk (2001) uses the measurement of the component-based approach, consists from the technical change, changes in technical efficiency and scale change operation. TFP measurement results indicate that rice productivity growth as a result of more usage from the one input and interaction among input in Malang Regency from the the rainy season to the dry season there is an increase in the amount of 0.44 , but not proportionally with the addition of all inputs used. Meanwhile, the data from the year 2000 - 2013 on average for 11 years productivity growth over the use of input rice acreage of 0.84 .

Table 8 - Source of Productivity Growth

\begin{tabular}{lc}
\hline \multicolumn{1}{c}{ Element of TFP } & Number \\
\hline \hline Technical changes & 1.59 \\
Efficiency Scale changes & 0.31 \\
Efficiency changes Technical & 0.89 \\
\hline TFP & 0.44 \\
\hline \hline
\end{tabular}

Analysis of the source of productivity growth caused by three things: the first is a technical change; can be analysed how farmers use the technology in allocating the inputs from the season to season. There is a shift in technological rise of 1.59 means that increasing productivity growth at $1.59 \%$ due to the addition of the use of inputs by $1 \%$. 
While the second source is the change in technical scale, analysed how the farmer's ability to perform substitution between inputs to increase production. Result demonstrate that there is a rise in productivity growth of $0.31 \%$ due to an increase in technical scale by $1 \%$.

Technical scale shows decreasing returns to scale; occurs in the addition of land use, seeds, ZA, SP-36, organic fertilizers, male labour, solid and liquid chemical drugs. And the decline in production will be experienced by the additional use of urea, NPK Phonska fertilizers and female labour. The use of these inputs that needs attention, because the more added will further reduce production.

Table 9 - Changes in the Technical Scale

\begin{tabular}{ccc}
\hline Variables & Technical Scale & Return to scale \\
\hline A & 0.022 & Decreasing Return to scale \\
B & 0.152 & Decreasing Return to scale \\
Z & -0.722 & Decreasing of Production \\
ZA & 0.864 & Decreasing Return to scale \\
SP & -0.272 & Decreasing of Production \\
O & 0.137 & Decreasing Return to scale \\
TL & 0.115 & Decreasing Return to scale \\
TP & 0.161 & Decreasing Return to scale \\
OK & -0.319 & Decreasing of Production \\
Ol & 0.166 & Decreasing Return to scale \\
Total & 0.007 & Decreasing Return to scale \\
\hline \hline
\end{tabular}

The third Source of of productivity growth is the change in technical efficiency. Rice productivity growth in Malang Regency $0.89 \%$ due to the increase of technical efficiency of $1 \%$. Technical efficiency analysis of the how farmers can be able to improvise operationally in allocating the inputs in the achievement of the potential production of the time to time. Where the level of efficiency achieved in the rainy season of 0.504 , and 0.5683 for the dry season, so the achievement of technical efficiency becomes 0.89 .

\section{CONCLUSION}

Based on the results, it can be formulated that:

$77.7 \%$ of the farmers have a preference of risk averter (farmers who prefer to avoid the risk). Risk averter farmers use inputs (seeds, labour and fertilizer) at least compared to other types of preferences, except for chemical drugs. Although the costs incurred by farmers averter risk are smallest, but due to the resulting production is also the least, then the benefits at least compared to the others.

Preferences farmer have positive influence on the level of productivity of rice farming, but not proven significantly.

Value of Total Factor Productivity of farming in Malang Regency (Indonesia) is still slow in the amount of 0.44 .

\section{RECOMMENDATION}

We recommend guidance and extension at the time of adoption of the technology is always carried out in order to have an impact on the application of technology in accordance with the recommendation. Therefore contributes to the increase in profits of rice farmers, productivity and the rate of TFP. 


\section{REFERENCES}

1. Balk,B.M.,2001. Scale Efficiency and Productivity Change. Journal of Productivity Analysis, 15, page 159-183. Kluwer Academic Publisher, Boston.

2. Battese, G. E., \& Coelli, T. J. (1992). Frontier production functions, technical efficiency and panel data: With application to paddy farmers in India. Journal of Productivity Analysis, 3(1/2), 153-169.

3. Battese,G.E., and T.J.Coelli, 1995. A Model for Technical Inefficiency Effects in a Stochastic Frontier Production Function for Panel Data. Empirical Economics, 20:325332

4. Casu B, Girardone $C$ and Molyneux $P, .2002$. Productivity Change in Europe Banking: $A$ Comparison Of Parametric and Non-Parametric Approaches. Discussion Paper no.04-01

5. Coelli, T. 1995. Recent Developments in Frontier Modelling and Efficiency Measurement. Australian Journal of Agricultural Economics, 39 (3): 219-245

6. A guide to Frontier Version 4.1: A Computer Program for Stochastic Frontier Production and Cost Function Estimation. Centre for Efficiency and Productivity Analysis (CEPA), 1996. Working Paper 7/96. University of New England, Armidale, pp 1-33.

7. An Introduction to Efficiency and Productivity Analysis. Second Edition. Springer, 2005. USA, pp $241-261$

8. Coelli,T. Rao DSP and Battese GE,1998. An Introduction to Efficiency and Productivity Analysis, Kluwer Academic Publisers. London.

9. Constantin,P.D,, Martin,A.L., and Rivera EDBB, 2009. Cobb-Douglas,Translog Stochastic Production and Data Envelopment Analyisis in Total Factor Productivity in Brazilian Agribusiness. The Flagship Research Journal Of International Conference of The Production and Operations Management Society. Vol 2. No 2.

10. Fare R, Grosskopf S, Norris M and Zhang Z.,1994. Productivity Growth, Technical Progress, and Efficiency Change in Industrilized Countries.

11. Ellis, Frank, 1988. Peasant Economics, Farm Household and Agrarian Development, Cambridge University Press.

12. Fariyanti, A., 2008. Household Economic Behaviour of Vegetable Farmers to Face the Production and Product Price Risks in Pengalengan District, Bandung Regency. Doctoral Dissertation. IPB Graduate School.

13. Fauziyah, E., Hartoyo, S., Kusnadi, N., Kuntjoro, S. U., 2010. Analisis Produktivitas Usahatani Tembakau di Kabupaten Pamekasan. Indonesia. Jurnal Organisasi dan Manajemen, 6: 119-131.

14. Guan H.Wan and George E.Battese, 1992. A Stochastic Frontier Production Function Incoporating Flexible Risk Properties. Paper presented at the Australian Meeting Of The Econometric Society, Monash University, Melbourne, 6-8 July 1992

15. Harwood, et al. 1999. Managing Risk in Farming: Concepts, Research and Analysis. Agricultural Economic Report No.774. Market and Trade Economic Division and Resource Economics Division, Economic Research Service U.S. Department of Agriculture.

16. Hamal, B.K., Risk Aversion, Risk Perception and Credit Use: The Case of Small Paddy Farmers in Nepal. 1983. Research Paper Series, number 21, May 1983. HMG-US AIDA/D/C Project. Strengthening Institutional Capacity in the Food and Agricultural Sector in Nepal.

17. Ratnasari, I, 2013. Behaviour Analysis of Farmers against Organic Vegetable Farming Risk. A Case Study on Brenjonk Organic Community. Penanggungan Village, Trawas District, Mojokerto Regency, East Java, Not Published.

18. Semaoen,I. 1992. Ekonomi Produksi Pertanian. Teori dan Aplikasi. ISEI. Jakarta

19. Soekartawi, 1993. Risk and Uncertainty on Agribusiness. Theory and Application. PT. Raja Grafindo Persada. Jakarta.

20. Singh, I.J, 1980. Farm Decision under Uncertainty, Improving Farm Management Teaching in Asia, ADC inc, Bangkok 
21. Putri DI, 2014. Analysis of Perception of Paddy Farmers against Risk of Organic Paddy Agricultural System. Minor Thesis. University of Brawijaya. Not Published.

22. Just, R.E. and R.D. Pope, 1979. On the Relationship of Input Decisions and Risk. In: Roumasset, J.A., J.M. Boussard and I. Singh (Eds). Risk Uncertainty and Agricultural Development. Agricultural Development Council, New York.

23. Just, E.R, dan R.D. Pope. 1979. Production Function Estimation and Related Risk Consideration. American Journal Agricultural Economic, 6(2): 276-284.

24. JR.Anderson and WE. Griffiths.1982. Product Risk and Efficient Allocation of Resources. Australian Journal of Agricultural Economics, 26(3): 226-332.

25. Kumbhakar, C S. 2002. Specification and Estimation of Production Risk, Risk Preferences and Technical Efficiency. American Journal Agricultural Economic, 84(1) (Februari 2002): 8-22.

26. Kumbhakar,C.S. and C.A.Knox Lovell, Stochastic Frontier Analysis. Cambridge University Press

27. Kumbhakar,C.S and Tsionas E.G.,2008. Estimation of Cost vs Profit System with and without Technical Inefficiency. Academia Economic Papers. Vol 36:2. Page 145-166

28. Kumbhakar, C S. 2002. Specification and Estimation of Production Risk, Risk Preferences and Technical Efficiency. American Journal Agricultural Economic, 84(1) (February 2002): 8-22.

29. LWayo,MK,2012. Risk Preferences and Consumption Decisions in Organic Production: The Case of Kwazulu-Natal and Eastern Cape Provinces of South Africa, Disertation. Universitas Fort Hare Afrika Utara.

30. Pope, Rulon D. And Randall A. Kramer. 1979. «Production Uncertainty and Factor Demans for the Competitive Firm». So. Econ. J., 46:489-501

31. Saptana,A. Daryanto, H. K. Daryanto and Kuntjoro, 2010. Analysis of Technical Efficiency of Big Red Chili Farming Production and Farmers Behaviour to Face the Risk. Jurnal Agro Ekonomi. Volume 28 No. 2: 153-188.

32. Sanglestsawai, 2012. Production Risk, Farmer Welfare and Bt Corn in the Philippines, Selected paper prepared for presentation at the Agricultural and Applied Economics Association, Seattle, WA, August 12-14,2012.

33. Siddik,M,. 2015. Household Economic Behaviour of Virginia Tobacco Farmers to Face the Farming Risk in Lombok Island, West Nusa Tenggara Province. Doctoral Dissertation. Graduate Program. Agriculture Faculty. Universitas Brawijaya. Malang. Indonesia

34. Ozden E and Santos,P,.2006. Decomposing Productivity Changes in The Ghanaian Cocoa Sector.Working Papers.

35. Wik,M., S. Holden and E.Taylor,1998.Risk, Market Imperfections and Peasant Adaptation: Evidence from Northern Zambia. Discussion Paper D-28, Department of Economics and Social Sciences. The Agricultural University of Norway.

\section{APPENDIX 1:}

$$
\left.(\mathrm{S} \widehat{T} \Delta)=\hat{\xi}_{b}+\left(\hat{\xi}_{u}\right)+\left(\hat{\xi}_{z a}\right)+\widehat{\xi}_{p s}\right)+\left(\hat{\xi}_{s p}\right)+\left(\hat{\xi}_{o}\right)+\left(\hat{\xi}_{t l}\right)+\left(\hat{\xi}_{t p}\right)+\left(\hat{\xi}_{o b k}\right)+\left(\hat{\xi}_{o b l}\right)
$$

Where $\hat{\xi}_{b}$ is changes in technical scale because of the use of seeds, with the equation (9):

$$
\hat{\xi}_{b}=\hat{\beta}_{b}+\hat{\beta}_{b t} t+\hat{\beta}_{b u} \ln B_{i t} \ln U_{i t}+\hat{\beta}_{b z a} \ln B_{i t} \ln Z A_{i t}+\hat{\beta}_{b p s} \ln B_{i t} \ln P S_{i t}+\hat{\beta}_{b s p} \ln B_{i t} \ln S P_{i t}+
$$

$\hat{\beta}_{b o} \ln B_{i t} \ln O_{i t}+\hat{\beta}_{b t l} \ln B_{i t} \ln T L_{i t}+\hat{\beta}_{b t p} \ln B_{i t} \ln T P_{i t}+\hat{\beta}_{b o b k} \ln B_{i t} \ln O B K_{i t}+\hat{\beta}_{b o b l} \ln B_{i t} \ln O B L_{i t}$

$\hat{\xi}_{u}$ is changes in technical scale due to the use of urea, with equation (10):

$$
\begin{gathered}
\hat{\xi}_{u}=\hat{\beta}_{u}+\hat{\beta}_{u t} t+\hat{\beta}_{u b} \ln B_{i t} \ln U_{i t}+\hat{\beta}_{u z a} \ln U_{i t} \ln Z A_{i t}+\hat{\beta}_{u p s} \ln U_{i t} \ln P S_{i t}+\hat{\beta}_{u s p} \ln U_{i t} \ln S P_{i t}+ \\
\hat{\beta}_{u o} \ln U_{i t} \ln O_{i t}+\hat{\beta}_{u t l} \ln U_{i t} \ln T L_{i t}+\hat{\beta}_{u t p} \ln U_{i t} \ln T P_{i t}+\hat{\beta}_{u o b k} \ln U_{i t} \ln O B K_{i t}+\hat{\beta}_{u o b l} \ln U_{i t} \ln O B L_{i t}
\end{gathered}
$$


$\hat{\xi}_{z a}$ is changes in technical scale due to the use of ZA fertilizer, with equation (11):

$$
\begin{gathered}
\hat{\xi}_{z a}=\hat{\beta}_{z a}+\hat{\beta}_{z a t} t+\hat{\beta}_{z a b} \ln Z A_{i t} \ln U_{i t}+\hat{\beta}_{z a u} \ln U_{i t} \ln Z A_{i t}+\hat{\beta}_{z a p s} \ln Z A_{i t} \ln P S_{i t}+\hat{\beta}_{z a s p} \ln Z A_{i t} \ln S P_{i t}+ \\
\hat{\beta}_{z a o} \ln Z A_{i t} \ln O_{i t}+\hat{\beta}_{z t l} \ln Z A_{i t} \ln T L_{i t}+\hat{\beta}_{z a t p} \ln Z A_{i t} \ln T P_{i t} \\
+\hat{\beta}_{z a o b k} \ln Z A_{i t} \ln O B K_{i t}+\hat{\beta}_{z a o b l} \ln Z A_{i t} \ln O B L_{i t}
\end{gathered}
$$

Equation (12) is changes in technical scale due to the use of NPK Phonska fertilizer:

$$
\begin{gathered}
\hat{\xi}_{p s}=\hat{\beta}_{p s}+\hat{\beta}_{p s t} t+\hat{\beta}_{p s b} \ln P S_{i t} \ln B_{i t}+\hat{\beta}_{p s u} \ln U_{i t} \ln P S_{i t}+\hat{\beta}_{z a p s} \ln Z A_{i t} \ln P S_{i t}+\hat{\beta}_{p s s p} \ln P S_{i t} \ln S P_{i t}+ \\
\hat{\beta}_{p s o} \ln P S_{i t} \ln O_{i t}+\hat{\beta}_{p s t l} \ln P S_{i t} \ln T L_{i t}+\hat{\beta}_{p s t p} \ln P S_{i t} \ln T P_{i t} \\
+\hat{\beta}_{p s o b k} \ln P S_{i t} \ln O B K_{i t}+\hat{\beta}_{p s o b l} \ln P S_{i t} \ln O B L_{i t}
\end{gathered}
$$

Equation (13) is changes in technical scale due to the use of SP-36 fertilizer:

$$
\begin{gathered}
\hat{\xi}_{s p}=\hat{\beta}_{s p}+\hat{\beta}_{s p t} t+\hat{\beta}_{s p b} \ln S P_{i t} \ln B_{i t}+\hat{\beta}_{s p u} \ln U_{i t} \ln S P_{i t}+\hat{\beta}_{s p p s} \ln S P_{i t} \ln P S_{i t}+\hat{\beta}_{s p z a} \ln Z A_{i t} \ln S P_{i t}+ \\
\hat{\beta}_{s p o} \ln S P_{i t} \ln O_{i t}+\hat{\beta}_{s p t l} \ln S P_{i t} \ln T L_{i t}+\hat{\beta}_{s p t p} \ln S P_{i t} \ln T P_{i t} \\
+\hat{\beta}_{s p o b k} \ln S P_{i t} \ln O B K_{i t}+\hat{\beta}_{s p o b l} \ln S P_{i t} \ln O B L_{i t}
\end{gathered}
$$

Equation (14) is changes in technical scale due to the use of Organic Fertilizer:

$$
\hat{\xi}_{o}=\hat{\beta}_{o}+\hat{\beta}_{o t} t+\hat{\beta}_{o b} \ln O_{i t} \ln B_{i t}+\hat{\beta}_{o u} \ln U_{i t} \ln O_{i t}+\hat{\beta}_{o p s} \ln O_{i t} \ln P S_{i t}+\hat{\beta}_{o z a} \ln O_{i t} \ln S P_{i t}+
$$

$\hat{\beta}_{o z a} \ln Z A_{i t} \ln O_{i t}+\hat{\beta}_{o t l} \ln S P_{i t} \ln T L_{i t}+\hat{\beta}_{o t p} \ln O_{i t} \ln T P_{i t}+\hat{\beta}_{o o b k} \ln O_{i t} \ln O B K_{i t}+\hat{\beta}_{o o b l} \ln O_{i t} \ln O B L_{i t}$

Equation (15) is changes in technical scale due to the use of male labour:

$$
\hat{\xi}_{t l}=\hat{\beta}_{t l}+\hat{\beta}_{t l t} t+\hat{\beta}_{t l b} \ln O_{i t} \ln B_{i t}+\hat{\beta}_{o u} \ln U_{i t} \ln O_{i t}+\hat{\beta}_{o p s} \ln O_{i t} \ln P S_{i t}+\hat{\beta}_{o z a} \ln O_{i t} \ln S P_{i t}+
$$

$\hat{\beta}_{o z a} \ln Z A_{i t} \ln O_{i t}+\hat{\beta}_{o t l} \ln S P_{i t} \ln T L_{i t}+\hat{\beta}_{o t p} \ln O_{i t} \ln T P_{i t}+\hat{\beta}_{o o b k} \ln O_{i t} \ln O B K_{i t}+\hat{\beta}_{o o b l} \ln O_{i t} \ln O B L_{i t}$

Equation (16) is changes in technical scale due to the use of female labour:

$$
\begin{gathered}
\hat{\xi}_{t p}=\hat{\beta}_{t p l}+\hat{\beta}_{t p t} t+\hat{\beta}_{t p b} \ln T P_{i t} \ln B_{i t}+\hat{\beta}_{t p u} \ln T P_{i t} \ln U_{i t}+\hat{\beta}_{t p p s} \ln T P_{i t} \ln P S_{i t}+\hat{\beta}_{t p z a} \ln T P_{i t} \ln Z A_{i t}+ \\
\hat{\beta}_{t p o} \ln T P_{i t} \ln O_{i t}+\hat{\beta}_{t p t l} \ln T P_{i t} \ln T L_{i t}+\hat{\beta}_{t p s p} \ln T P_{i t} \ln S P_{i t} \\
+\hat{\beta}_{t p o b k} \ln T P_{i t} \ln O B K_{i t}+\hat{\beta}_{t p o b l} \ln T P_{i t} \ln O B L_{i t}
\end{gathered}
$$

Equation (17) is changes in technical scale due to the use of solid chemical drug:

$$
\begin{gathered}
\hat{\xi}_{\text {obk }}=\hat{\beta}_{o b k l}+\hat{\beta}_{o b k t} t+\hat{\beta}_{o b k b} \ln O B K_{i t} \ln B_{i t}+ \\
\hat{\beta}_{\text {obku }} \ln O B K_{i t} \ln U_{i t}+ \\
\hat{\beta}_{o b k o} \ln O B K_{i t} \ln O_{i t}+\hat{\beta}_{\text {obktl }} \ln O B K_{i t} \ln T L_{i t}+\hat{\beta}_{o b k s p} \ln O B K_{i t} \ln S P_{i t} \\
+\hat{\beta}_{t p o b k} \ln T P_{i t} \ln O B K_{i t}+\hat{\beta}_{o b k o b l} \ln O B K_{i t} \ln O B L_{i t}
\end{gathered}
$$

Equation (18) is changes in technical scale due to the use of liquid chemical drug:

$$
\begin{gathered}
\hat{\xi}_{o b l}=\hat{\beta}_{o b l}+\hat{\beta}_{o b l t} t+\hat{\beta}_{o b l b} \ln O B L_{i t} \ln B_{i t}+ \\
\hat{\beta}_{o b l u} \ln O B L_{i t} \ln U_{i t}+\hat{\beta}_{o b l u} \ln O B L_{i t} \ln U_{i t}+\hat{\beta}_{o b l p s} \ln O B L_{i t} \ln P S_{i t}+\hat{\beta}_{o b l z a} \ln O B L_{i t} \ln Z A_{i t}+ \\
\hat{\beta}_{o b l o} \ln O B L_{i t} \ln O_{i t}+\hat{\beta}_{o b l t l} \ln O B L_{i t} \ln T L_{i t}+\hat{\beta}_{o b l s p} \ln O B L_{i t} \ln S P_{i t} \\
+\hat{\beta}_{o b l o b k} \ln O B L_{i t} \ln O B K_{i t}+\hat{\beta}_{o b l s p} \ln O B L \ln S P_{i t}
\end{gathered}
$$




\section{APPENDIX 2:}

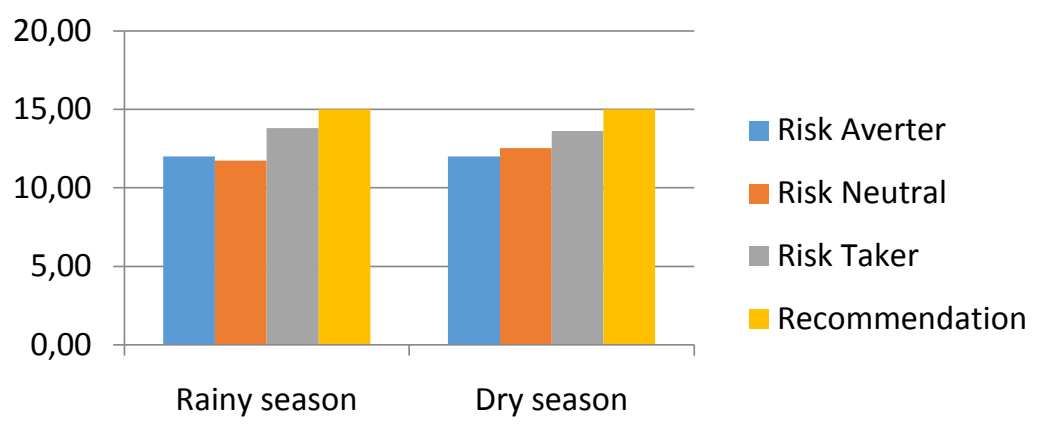

Figure 1 - The Use of Seeds Based on Behaviour of Farmers Risk

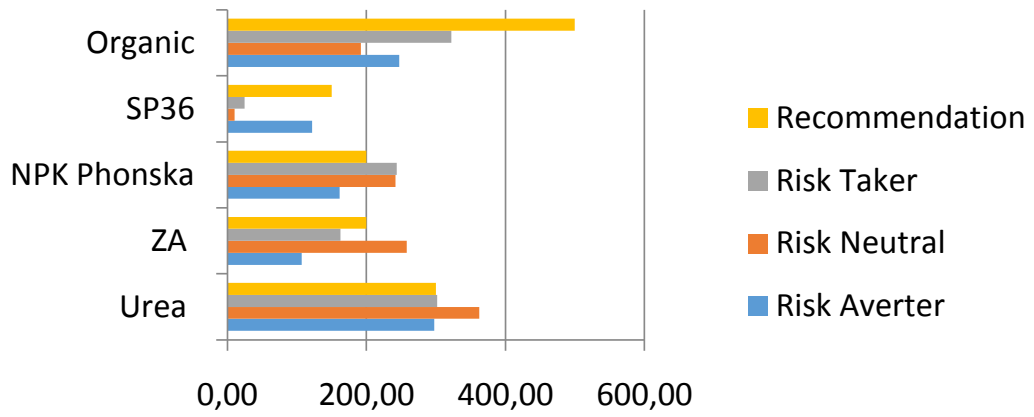

Figure 2 - The Use of Fertilizer (kg) on Rainy Season

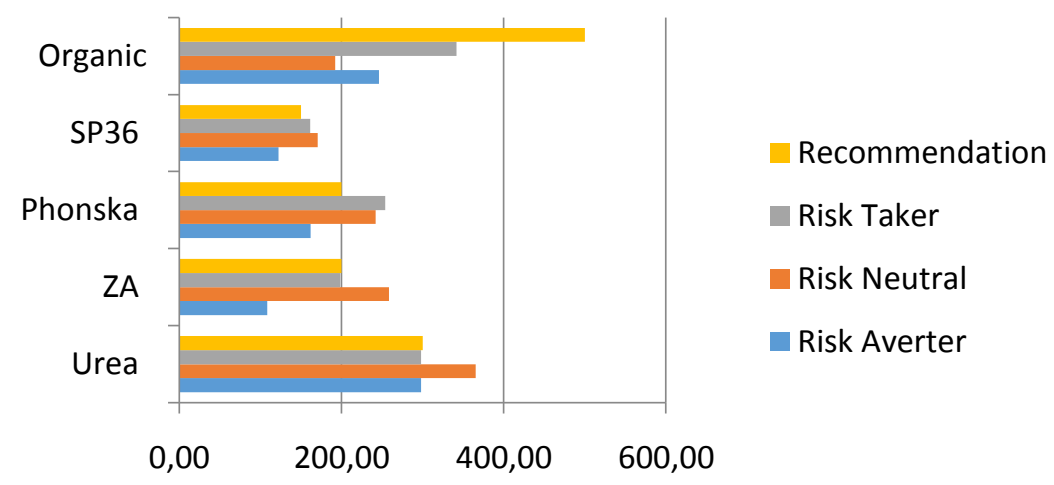

Figure 3 - The Use of Fertilizer (kg) on Dry Season

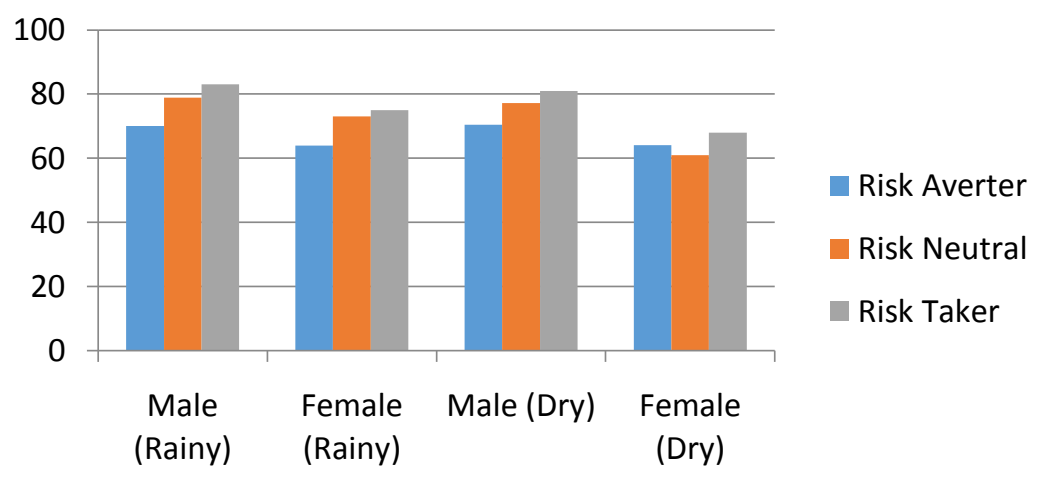

Figure 4 - The Use of Labour (Man-day) 
15,00

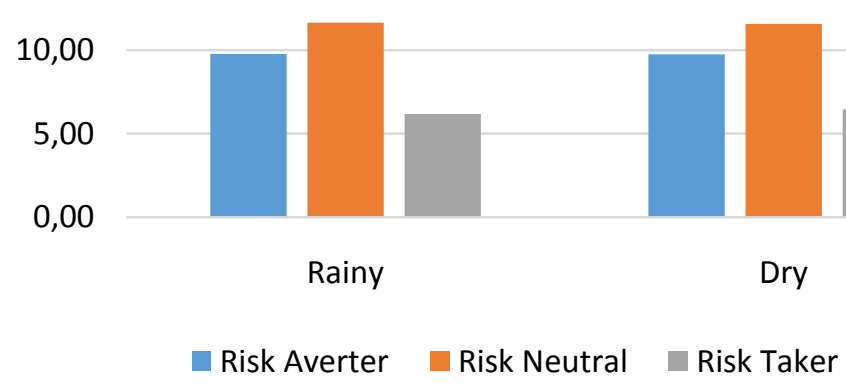

Figure 5 - The Use of Solid Chemical Drug $(\mathrm{kg})$

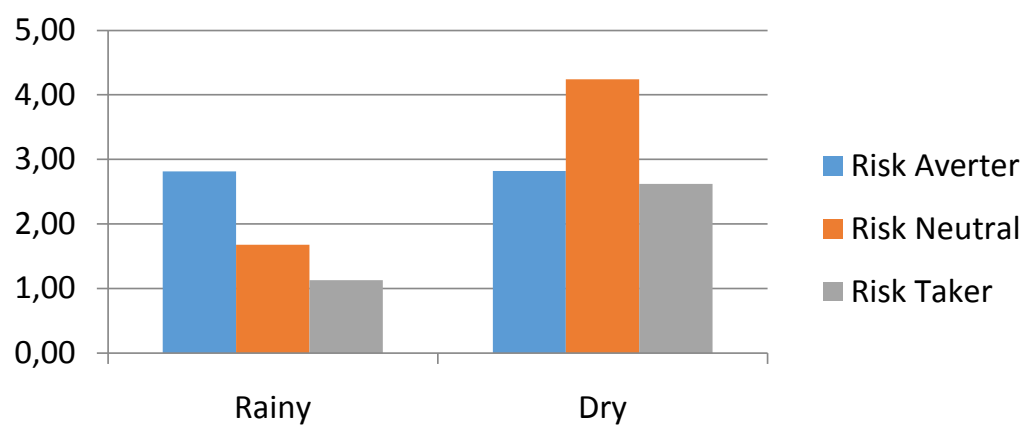

Figure 6 - The Use of Liquid Chemical Drug (litter)

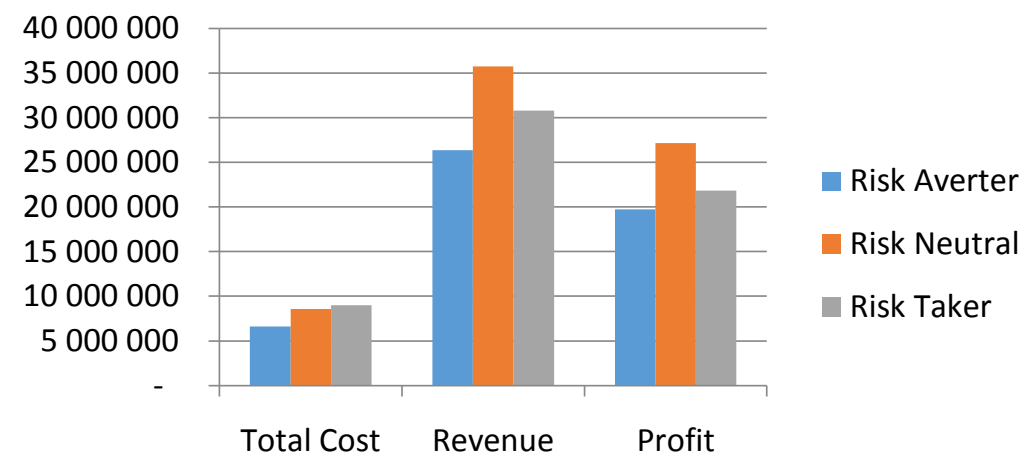

Figure 7 - Total Cost, Revenue and Profit on Rainy Season

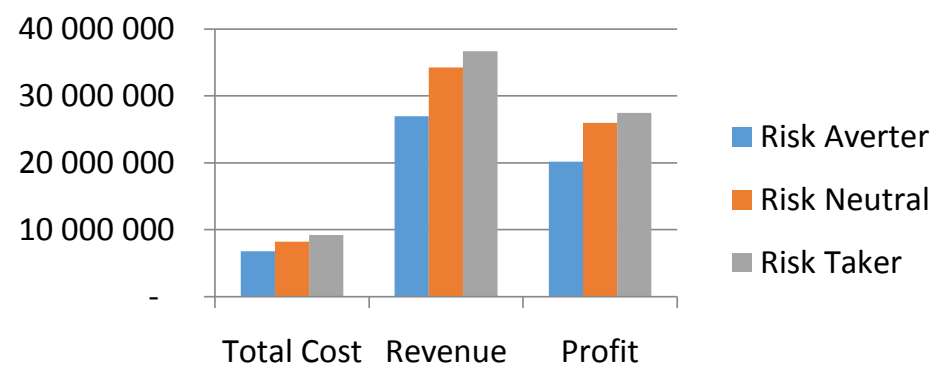

Figure 8 - Total Cost, Revenue and Profit on Dry Season 